\title{
STUDIES ON FREE AMINO ADIDS AND C-REACTIVE PROTEIN IN PERILYMPH OF GUINEA PIGS
}

\author{
By \\ YUTAKA SAKAMOTO \\ From the Department of Oto-Rhino-Laryngology, School of Medicine \\ Keio University, (Director: Y. Suzuki)
}

Free amino acids and $\mathrm{C}$-reactive protein in the perilymph and cerebrospinal fluid of guinea pigs was analysed and the following results were obtained.

1) Under normal condition, seven free amino acids : glutamine, alanine, threonine, glycine, serine, glutamic acid and aspartic acid were found in the perilymph.

2) By soft palate irritation, four other amino acids which were never seen in the normal, appeared in the perilymph. They were cysteic acid, arginine, histidine and lysine.

3) Free amino acids normally seen in the cerebrospinal fluid of guinea Pigs were: glutamine, alanine, threonine, glycine, serine, glutamic acid, aspartic acid, arginine, histidine, lysine, valine and leucine.

On the contrary to findings of the perilymph, no change was noticed in the composition of amino acids in the cerebrospinal fluid by soft palate irritation.

4) Furthermore, C.R.P. of the perilymph, cerebrospinal fluid and blood serum was also investig. ated. It's appearance was observed by soft palate irritation while it was negative under normal condition.

\section{モルモツト外リンパ液の遊離アミノ酸 及びC.R.Pに関する研究}

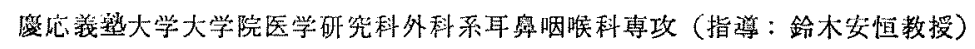

坂李李裕

目次

第 1 部 正常時モルモット外リンパ液の遊離アミノ酸に ついて

第1章 舶言

第2 章 实驗方法

第3 章 実戨 結果

第 4 章 総括及び考按

第 5 章 結語

第 2 部 口蓋刺激時モルモット外リンパ液の遊離アミノ

$$
\text { 酸について }
$$

第1 章 楮言

第2 章 整䮖方法

第3章 実踽 結 果

第 4 章 総括及び考按
第 5 章 結語

第3 部 モルモット䯣液の遊離アミノ酸について

第 1 章 楮咅

第2 章奏㧎力法

第 3 章 実跧 結果

第 4 章 総括及び考按

第 5 章 結 語

第 4 部 モルモット外リンパ液, 髓液, 血清中の C.R.P.

$$
\text { について }
$$

第 1 章 緒言

第 2 章 实鍳方法

第3 章 実㢦結果

第 4 章 総括及び考掞

第 5 幦 絬 部

参苦文献 
第 1 部 正常時モルモツト外リ

\section{第 1 章 緒 言}

内耳液は音響刺激を外界から聴覚受容器入伝達する媒 体として，又内耳物質代謝に扎ける transmitter とし て，唖めて重要な役割を演していることは云うまでもな い.したがつて種々の内耳疾患の病因を追究するために は, この内耳液の生化学的研究は不可欠の問題である.

しかしながら，検体を得ることの困難さと，そのあま りの微量さとにさをたげられて，この問題はかなり古く から注目されているともかかはらず，な㧤分な成果が 得られていない。

ここに私は此較的微量にて測定し得られ，かつ内耳物 質代絊の重要な一環をなすと考兄られる遊離アミノ酸を 一つの示絜として選び, 種々の条件下に的けるその消長 から内耳の動的機構の一端をさぐろう之試み，その第一 段階としてまず正常モルモットの外リンパ夜游離アミ， 酸の測定を行つた。

\section{第 2 章 実験方法}

実験動物として体重 300 400g, 主に雄性のアルビ， モルモツトを用いた，その際特に鼓膜所見正常，プライ エル反射正常のるののみを選んだ.

なほ，内耳液中，内リンバ液はマミノ酸の分析を行う に足る量を得るためには 20 互以上の動物を用いねばな らず，実験に適さないので今回は比較的多量に採取し得 る外リンバ夜のみを対象とした。

外リンパ液の採取飞当つては, Aldred et al 2), Rüedi 42), Smith et al ${ }^{47)}$, 松生 ${ }^{31)}$ らによる記截を参考として 行つた. 即ち実験動物を䐆醉後断頭, 急速に失血死せし め，中耳骨胞を開放し，鼓膜を破り耳小骨を除志し，先 端直経約 $0.1 \mathrm{~mm}$ の毛細管ピペットを朋いて, 双眼実体 顕徽鏡下に正円空上り外リンパ液を採取する。毛細管ピ ペットはマイクロマニプレーターに装着するが，惯れれ ば直接手を用いて行うことも可能である。この際先端は 深部にまで刺入せず毛細管現象により自然に吸引させ

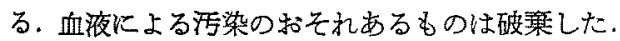

このようにして採取し得る外リンパ液は 1 耳平均約 3 $\mathrm{mg}$ である.この 5 頭 10 耳分約 $30 \mathrm{mg}$ を 1 回の実験に 供した.

動物の麻酔方法，殺害方法の外リンパ液組成に対する 影響の有無を知るために，無麻醉，エーテル麻䣲，ウレ タン麻醉の群, 又断頭死，心荿穿刺失血死，冷凍死の群 についてそれぞれ比較榆討した。
な拉ウレタン麻醉は $25 \%$ ウレタン溶液約 $2 \mathrm{cc}$ 腹腔内 注射, 冷凍死は $-60^{\circ} \mathrm{C}$ のドライアイスアルニール液中 投下によるものである.

採取した量の測定は重量法により行つた。即ち $0.1 \mathrm{mg}$ まで計量しらる島津製電気科法より採取した毛細管ピペ ットごと測定し，外リンパ液をとり出し後再びピペット の重量を測定し，その差を採取した外リンバ液の量とし た.

このようにして採取, 計量された外リンパ液の遊離了 ミノ酸を二次元ペーパークロマトグラフ法により測定し た.

測定に用いた渴紙は東洋渴紙製 No. 51 二次元用 40 $\mathrm{cm} \times 40 \mathrm{~cm}$ のむのである. この濾紙の一端に温風で乾 かしながら試料をそのままスポットした、この程度の 量, 濃度では特に除蛋白その他の処理は必要としない。

展開溶媒としては 4:1のフェノール：水及び 4:1:1 のブタノール:醋酸: 水をそれぞれの次元に用いた、試薬 は市股の特級品ならばそのままでる使用炕堪光るが，フ エノールのみは再蒸溜を行つた方が好結果が得られる.

この溶媒をそれぞれ䙳用の装置（東洋濾紙製ペーパー クロマトグラフイーキナビネット E-IP) 中に充たし,

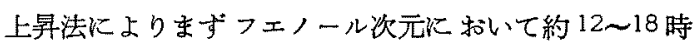
間展開し，約 $30 \mathrm{~cm}$ 浸透し大㴓紙を 48 時間以上風乾， 完全に乾燥させ，次いでブタノール次元にて同様約 12〜 18 時間前者と直角隹交叉する方向に展開する。乞して これを的 2 時間乾燥させ，次いで $0.2 \%$ ーンヒドリン・ エチルアルコール溶液に浸し, 乾橾後 $65^{\circ} \mathrm{C} の$ hot plate にて 30 分間加熱発色させる。発色させた溜紙はまもな く裉色するので $10 \%$ 硝酸銅を散布，固定すれば保存に 便利である。

展開温度は室温とした，恒温装置はかえつてむらが生 じるため好ましくない，冬期はさけたため特に実験結果 と支障はきたさなからた。

このようにして展開，発色させたつミ／酸は，1回の 実験每に温度その他の 条件の差によつて RF に微妙な 差を生ずるので，正確を期するため両端䎲一次元で展開 させた標準アミノ酸と比較しながら定性を行つた ${ }^{58)}$.

\section{第 3 章 実 験 結 果}

源紙上に現れたアミノ酸は，第】表に見られるごとく ほとんど全例に批いて次の 7 種である。すなはちグルタ ミン, アラニン, スレオニン, グリシン, セリン, グル タミン酸、アスパラギン酸である.表中十は明膫に，士 は痕跡,一は認め得なかつたことを意味する。 
第 1 表 正常モルモット外リンバ遊離アミノ酸

\begin{tabular}{|c|c|c|c|c|c|c|c|c|}
\hline 験 & $\begin{array}{l}\text { 外 } \\
1 \\
y \\
\therefore 9 \\
\text { 量 } \\
\text { mg }\end{array}$ & 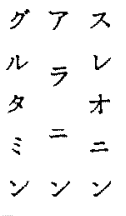 & $\begin{array}{l}\not ゙ \\
y \\
\text { シ } \\
\text { ン }\end{array}$ & $\begin{array}{l}\text { 七 } \\
y \\
\text { ע }\end{array}$ & & & $\begin{array}{l}\text { アヒり } \\
\text { ルス } \\
\text { ギチジ } \\
\text { ニヂ } \\
\text { ンンン } \\
\end{array}$ & 觔 \\
\hline 19 & 33 & $+t+$ & + & + & & & - & 断 頡 死 \\
\hline 20 & 38 & $t+t$ & + & + & & & - & $"$ \\
\hline 21 & 35 & $t+t$ & + & + & & & - & 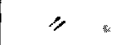 \\
\hline 22 & 31 & $t+t$ & + & + & & & - & $\Rightarrow$ \\
\hline 30 & 33 & $+t+$ & + & + & & & \pm & " \\
\hline 33 & 39 & $t+t$ & + & + & + & & \pm & " \\
\hline 37 & 33 & $t+t$ & + & + & & & \pm & 心躟穿刺 \\
\hline 38 & 24 & $t+t$ & + & 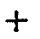 & & & - & 冷涷死 \\
\hline
\end{tabular}

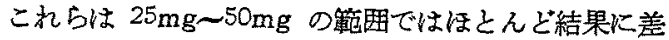
はみられないが, $20 \mathrm{mg}$ 以下の量では明膫に出現するの はグルタミンのみで，その他はほとんど判定不能とな る. 又定量的分析は行はなからたが，私の方法で梌出し 得る絶対量がダルタミンで約 $0.1 \boldsymbol{\gamma}$ ，その他のアミノ酸は

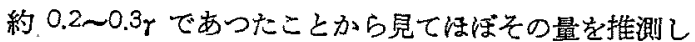
得る。

また前章にのべたごとく試料採取法の影響を各方法に ついて检討して見たが，第1表備考に示すごとく全く結 果に差を認めなかつた。

\section{第4章 総括及び考咹}

以上私はモルモツト外りンパ液から7種類の遊離了ミ ノ酸を梌出した。

内耳液の遊隻アミ，酸については系統的に分析を行つ たのは吉川 ${ }^{63)}$ (1955) 矯矢々するが，その後松生 ${ }^{31)}$ (1957)，Chevance (1958) による報告が見られる。乙 かしながら吉川，松生等は一次元ぺーパークロマトグラ フ法を用いたため 2〜4 種のアミノ酸を分析したに止ま つている. その後 Chevance? はモルモット外リンパ 液についてグルタミン, アラニン，スレオニン，グリシ ソセリン，グタミン酸の6種を分析しており，私の
今回の成續すほぼこれに近い結果を示している。

さて，これらのアミノ酸が有する意義については全く

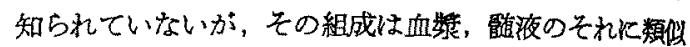
していることが知られる（第2表. 第3表）、モルモッ

第 2 表 正常人血槳中遊離アミノ酸

\begin{tabular}{|c|c|c|}
\hline $7 \quad \overline{ }=$ & ン & $2.6 \sim 5.3 \mathrm{mg} / 100 \mathrm{ml}$ \\
\hline フル $\neq=$ & ン & $1.1 \sim 3.5$ \\
\hline アスパラギン & 酸 & $0.9 \sim 1.2$ \\
\hline$\because x \bar{\tau} 1$ & Y & $0.8 \sim 2,0$ \\
\hline グルタ ミン & 酸 & $0.6 \sim 1.7$ \\
\hline 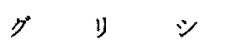 & $y$ & $1.3 \sim 2.3$ \\
\hline ヒス チ ヂ & ン & $1.1 \sim 1.8$ \\
\hline $1 \% \not 1 *$ & ン & $1.0 \sim 2.2$ \\
\hline a $1 \quad$ & 2 & $1.3 \sim 2.5$ \\
\hline シ & ע & $2.1 \sim 3.8$ \\
\hline × $\neq$ 才 & $y$ & $0.3 \sim 0.6$ \\
\hline フェニールアラ & V & $0.5 \sim 2.2$ \\
\hline $7^{\circ} \quad \square \quad 1$ & ン & $2.4 \sim 2.7$ \\
\hline$x \vee+=$ & ン & $1.1 \sim 2.9$ \\
\hline 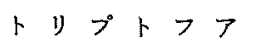 & ע & $0.7 \sim 1.5$ \\
\hline f $\quad$ a $\quad \forall$ & $y$ & $0,8 \sim 2,2$ \\
\hline バ ｙ & ע & $2.2 \sim 3.5$ \\
\hline
\end{tabular}

第 3 表 正常人䯣液中遊離アミノ酸

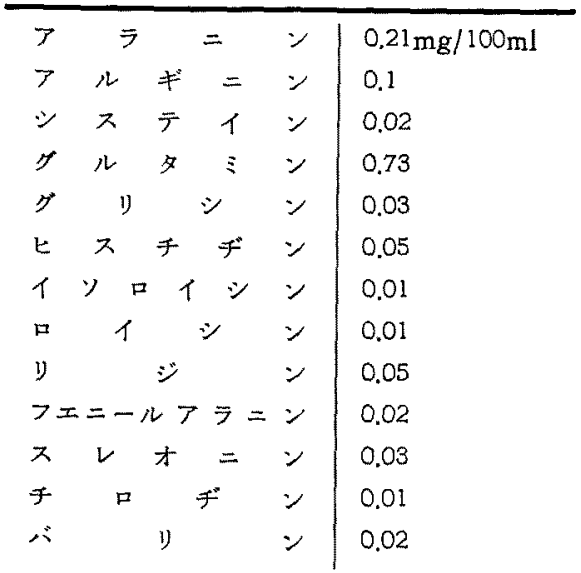

第 4 表 踷動物脳中遊離了ミ，酸 (55)

\begin{tabular}{|c|c|c|c|c|c|c|}
\hline & & グルタミン酸 & グルタミン & $r ア ミ ノ$ 酪酸 & アスパラギン酸 & $\begin{array}{l}\text { ア ゼヂ } \\
\text { アスパラギ酸 }\end{array}$ \\
\hline$\star$ & & $8.7 \sim 9.9$ & 5.3 & $2.2 \sim 4.2$ & 2.2 & 6.0 \\
\hline ネ ズ & & $8.2 \sim 12.8$ & $2.1 \sim 6.4$ & $2.0 \sim 6.1$ & $1.7 \sim 2.8$ & $4,3 \sim 6.9$ \\
\hline$=\nabla+1$ & & $9.9 \sim 10.8$ & $1.9 \sim 4.1$ & $2.7 \sim 6.0$ & $2.5 \sim 3.8$ & $2.6 \sim 5.9$ \\
\hline ハツカネズ & & $11.5 \sim 17.5$ & 4.9 & $3.5 \sim 5.9$ & & 5.3 \\
\hline
\end{tabular}


トの数值は知られていないので人間の場合と比較した。 このことは神経系特に脳組織中に存在する遊離了ミ， 酸がグルタミン酸を中心とする分布を示すことに対比す ると興味深い(第 4 表).

これに関運して私外外リンパ液中には上記の条件下で は $\boldsymbol{r}$ アミノ酷酸は榆出し得ないことをたしかめた。こ れらのことかららす外リン八液の関与する範盲において内 耳のアミノ酸代謝は脳神絟䒺のグルタミン酸代謝とは別 個の過程に叔いてなされているであろうことが想像され る. 将来内リンパ液中の遊離アミ，酸の分析が成功すれ ばこの意味においても極めて與味ある知見を加え得るこ とになるであるら

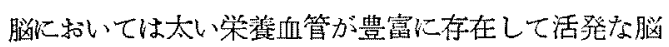
代謝をまかなつているが，Corti 器はそれ自身の血管を
有していないたる，栄幕の供㣛はもつばら内耳液にたよ ることになる。このことが内耳に代謝㜔害をきたし易い

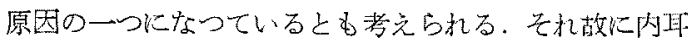

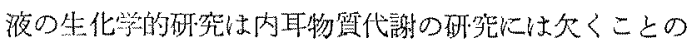
できないるのである，そして Tonndorf 5゙) の述べるご とく tunnel 中を充たす液が内リンパでななく外リンパ 性のものであると古礼ば，外リンパは内リンパ同様直接 队㷅代謝汇参加していることになると云えよう。

\section{第5章 結 語}

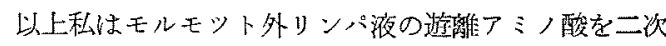
元ペーパークロマトグラフ法によつて分析し,グルタミ ン, アラニン, スレオニン, グリンン, セりン,グルタ ミン酸, アスパラギン酸の7種のアミノ酸を検出した。

第2 部口蓋刺激時モルモツト外リンパ液の遊離アミノ酸について

\section{第 1 章 緒言}

Koch 以来数 10 年間，医学の主流は疾病の一次元的 追究にあつたが，近年ようやくその傾向を脱し，上り多

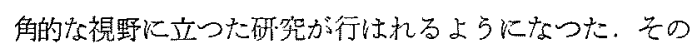
一つのさきがけとなつたのが Ricker ${ }^{41)}$, Speransky ${ }^{49}$ ), Reilly ${ }^{39)}$, Selye ${ }^{45}$ ), 更には Laborit ${ }^{25)}$ 等による研觉 である.

一方私の教室では, 哌桃摘出術中のショックの問題が 端緒となつて, 飯田 ${ }^{14)}$, 深沢 ${ }^{10)}$ 等によりモルモツトの 口蓋に刺激が加之られた㭙に片こるショックに関する研 究が行はれ，このショックが上にのベたような先筧者遙 によつて指摘された自律神経系, あるい情体副腎系 を主体とした生体反応に上るものであることを発表して いる.

その後我が教室においてひきつづき行はれた一連の研 究 15) 16) 24) 34) 36) 56) の結果，口蓋には豊富に自律神経が 分布して㧊り，ここに加えられた刺湤は自律神経を介し て㵙隔の臓器や組織につたわり，血管系を主体とするる奖 化をひき抗こするのであり，この変化は J. Reilly ${ }^{399}$ の所謂過剩刺激症候群比一政するものであることがたし かめられた。

更に Chevance 7) 8) 梳同様の方法に上つて外リンパ 液の組成に変動をきたすことを述べているので，私は口 蓋刺激によつて全身に藻起されるであるら変化の一部と

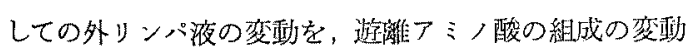
をその指標として追究せんと試みた。

\section{第 2 章 実験方法}

实験動物は算! 部にのべたと同椂のモルモットを用い た.

口盖刺湤の方法としては我が教室に批ける過去の経駼 14) から最も適したものとされているクロトン油の注り により行つた，クロトン油は八ズの種子から採取した植 物油であり，局所刺激性の極めて強いものであるが，油 性であるため吸収はされにくいものと思はれる、第5表 はクロトン油の成分を示したるのである。こ机はそれ単 独では刺激が強すざるために私はオリーが油によつて 1/5〜1/500 亿希䣋して用いた。

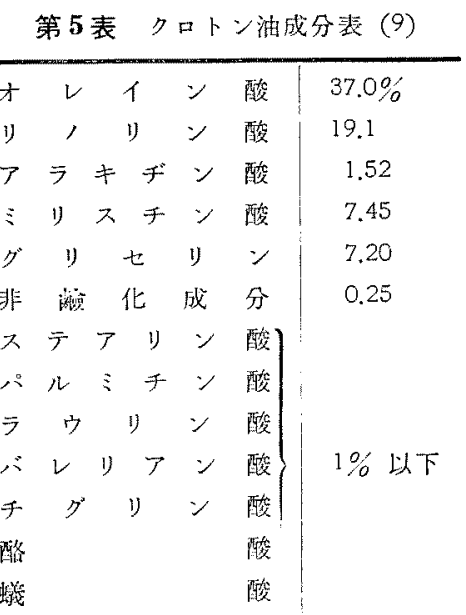




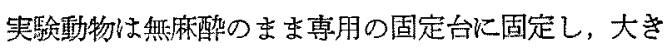
く開口させその雨側軟口蓋弓中央部附近に，額帯鏡照明 下に丁度扁摘時の局麻㕮注射之同じ要領で，粘膜下に上

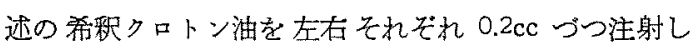
た.この際らまく注入できれば粘膜下に直経 $5 \mathrm{~mm}$ 前後 の水胞が形成されるのが明らかに観察される。

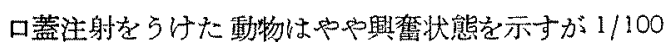
以上希釈されているクロトン油の場合には死亡すること はない。
注射後 1 時間経過した動物より第 1 部に述べた方法で 外リンパ液を採取し，その遊離アミノ酸を湘定した。

\section{第 3 章 実駼 結果}

その結果は正常時にみられるグルタミン, アラニン, スレオニン, グリシン，セリン，グルミン酸，アスハ ラギン酸の7種の他にシステイン酸, アルギニン, ヒス チヂン、リジンの4 種のアミノ酸が新たに出現している のが注目される(第6表).

私はこれらの新たなアミノ酸がクロトン油そのるのの

第6表 口蓋制激時モルモット外リンパ遊雄アミノ酸

\begin{tabular}{|c|c|c|c|c|c|c|c|c|c|c|c|c|}
\hline 夹 & $\begin{array}{c}\text { 外 } \\
y \\
y \\
\text { 量 }\end{array}$ & 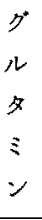 & $\begin{array}{l}\mathcal{P} \\
\bar{F} \\
=\end{array}$ & $\begin{array}{l}z \\
\nu \\
\text { オ } \\
-\end{array}$ & ע & セ & $\begin{array}{l}\not ゙ \\
ル \\
\text { タ } \\
\vdots \\
\text { ソ } \\
\text { 酸 }\end{array}$ & 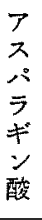 & $\begin{array}{l}y \\
x \\
\bar{\tau} \\
1 \\
y \\
\text { 酸 }\end{array}$ & $\begin{array}{l}\text { アヒり } \\
\text { ルス } \\
\text { ギチシ } \\
\text { ニヂ } \\
\text { 暗 }\end{array}$ & & 偀 \\
\hline 52 & 32 & + & + & + & + & + & + & + & + & + & $1 / 200$ & クロトン油 \\
\hline 56 & 42 & + & + & + & + & + & + & + & + & + & & " \\
\hline 57 & 43 & + & + & + & + & + & + & + & + & + & & " \\
\hline 68 & 49 & + & + & + & + & + & + & - & + & + & $1 / 500$ & クロトン油 \\
\hline 71 & 35 & + & + & + & + & + & - & - & + & + & & " \\
\hline 82 & 36 & + & + & + & + & + & + & + & + & + & & " \\
\hline 83 & 31 & + & + & + & + & + & + & + & + & + & & " \\
\hline 84 & 37 & + & + & + & + & + & \pm & + & + & $t$ & $1 / 200$ & クロトン油 \\
\hline
\end{tabular}

第 7 表 腹部皮下クロトン油注射後モルモット外リンパ遊離アミノ酸

\begin{tabular}{|c|c|c|c|c|c|c|c|c|c|c|c|c|}
\hline $\begin{array}{l}\text { 奏 } \\
\text { 験 } \\
\text { 丵 } \\
\text { 号 }\end{array}$ & $\begin{array}{l}\text { 外 } \\
y \\
y \\
\text { ng } \\
\text { 聂 } \\
\text { ng }\end{array}$ & $\begin{array}{l}ク ゙ \\
ル \\
タ \\
⿱ \\
ン\end{array}$ & $\begin{array}{l}\mathcal{P} \\
\bar{Y} \\
- \\
Y\end{array}$ & $\begin{array}{l}x \\
v \\
\lambda \\
= \\
=\end{array}$ & $\begin{array}{l}ク ゙ \\
y \\
\forall \\
ン\end{array}$ & 七 & 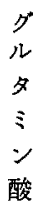 & 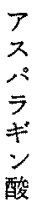 & $\begin{array}{l}シ \\
\text { ス } \\
\text { テ } \\
1 \\
Y \\
\text { 酸 }\end{array}$ & 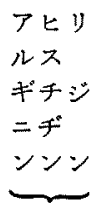 & & 珛 \\
\hline 32 & 35 & + & + & + & + & + & + & + & - & - & $1 / 200$ & クロトン浽 \\
\hline 41 & 42 & + & + & + & + & + & + & + & - & - & $1 / 5$ & 4 \\
\hline 42 & 35 & $t$ & + & + & + & + & + & + & \pm & - & & " \\
\hline 43 & 30 & + & + & + & + & $t$ & $t$ & + & \pm & - & $1 / 200$ & $"$ \\
\hline 44 & 33 & + & $t$ & $t$ & + & + & + & + & - & - & $1 / 500$ & $"$ \\
\hline
\end{tabular}

影響によつて出現したのかどうかを知るためにモルモッ ト腹部皮下に希鄱クロトン油を注射して比較して見た が，この望合はまつたく正常時と同様の構成を示すこと を知つた（第７表）。しか子腹部皮下の場合虫口蓝注射 に用いたよりも100倍す濃い1/5希粉のものに乱てを な打全く变化を示していない。

\section{第 4 章 総括及び考按}

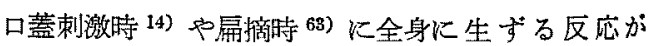
Reilly 現象に基ずくわのであることは先きにのへた道 りである.

すなわら口蓋に発した刺激が上頸部交㹂神経節 16) 60) をつたつて一旦中枢に達し51)，下降して全身各䁍器に血 
管運動神释の異常记起因する翌化を生ぜしめるるの思 はれるが，そのような変化は当然内耳にも及ぶものと考 えてよいであろう、すなわち内耳血管系の収縮や拉張， それにとるなら透過牲の荝進等一連の機能的変化が内耳 液の組成の変動をきたし得ることはむしろ当然と云えよ ら、しかしながらこの点を考えるに当つては内耳血管系 の機構やその特殊性，特にいはゆる hemato-labyrinthine barrier の問題, 内耳液生成の問題等に注目せ稀ば ならない.

即ら内，外リンパ液の生成機転については主として色 素，薬物を朋いて研究されてきたが，近年に至つては放 射性同位元素を用いての研究が種々行はれるよらにな つた.この場合外リンパ夜のみについて考えて見ると Key u. Retzius ${ }^{20)}$, Rüedi ${ }^{42)}$, Harrison ${ }^{13)}$, 坪井 ${ }^{57)}$, 後藤11等による研笲上り見て，外りンパ夜はをの多く を外リンパ腔壁ラセン鞓带血管より，そしてその一部を 蝸牛小管を通じて笝夜より受けていると考えるのが最も 妥当のように思はれる。

口蓋刺激によつてひきおこされる全身の血管性变化 は，それが極度に強い場合には不可逆性となり，内分必 系を含めて更に第二，第三の変化を誘発し，最終的には ショック死に至るのであるらが，私の夹験では刺激の強 度が比較的弱いために可逆性であり，血管の透過性が奖 化する程度に止まると思はれる。そして上述の外リンパ 生成機転の一部に異常がひき起され，䢐清中のアミノ酸 が遊出してきたものがこれら刺激時の双に見られる4種 のアミノ酸の起源であらう.内耳の的管系には脑に括け る blood-brain barrier と同じような hemato-labyrinthine barrier の存在することは Nomura ${ }^{33)}$, Ottaviani 35)その他によつてのぐられている通りである、脑に就い て子 $\gamma^{-}$アミノ酪酸は barrier を通過し得ないと云ら事 実もあり，システィン酸以下 4 種のアミ，酸が正常状態 に执いては barrier 劣通過し得ず，透過性の最進したと 見られる状態に执いてはじめて出現すると考えるのは必 ずしす不当ではない，むしこれが事実とすれば barrier に拉ける透過性はかなり複雑かつ徽娶な機構儿よつて統 御されているものと考学られる。このことについては教 室の日井 59) が精細な研究を行つているが，それによれ ば血管の透過性を高めると考えられる薬郕を投与した 場合には，上述の 4 種のアミノ酸が明らか出現するの である、つまりこの異常アミノ酸の出現はクロトン油に よる特巽的な变化ではなく， 口蓋刺激によつて白律神経 を介して生じた Reilly 現象の結果, 内耳血管系の透
過性昂進を起こしたことの一つの証左であるうと思はれ る.

内耳と自律神経の関係については, Portmann ${ }^{38)}$, Berger ${ }^{6)}$, 秋山 ${ }^{4)}$, 菊地 ${ }^{22)}$, 渡动 ${ }^{62)}$, 小出 ${ }^{23)}$, 岩田 ${ }^{18)}$, Perlman et al ${ }^{37)}$, Chevance 7) 8) 等出色々の角度から 諭じている。特に Chevance 7) はショック時のモルモ ット内耳の組織学的研究に执いて，血管条限局した毛 細管の漫出を示惨する所見を見ている。

これらの報告によつても自律神経の刺激によつてまず 最初に毛細管透過性が昆進し，その一つの現われとして 分子量の比較的大きなアミ，酸が遊出して来ると云ら仮 説もらなづけるところである。

Perlman \& Kimura ${ }^{37)}$ によつて推祭されたショック 時の内耳血管の麻痺的抬張はこのような变化の最終段階 であり，私の観察はその最初の段階であるとも云うこと がでさよう。

いずれにせよ出現した 4 種のフミノ酸そのものについ ては特に意義はなく，血中に普通に存在するるので，検 体の量を何倍かにすれば外リンバ液中にも正常状態に和 いて存在し得る可能性は充分である。たたその分子量が やや大であるためかそれ 以外の未知の理由によるのか barrier 自由に通過し得なかつたたけけ問題であるう。 従つてアミ，酸以外の物質に扟いても同様の態度をとる ものがあろらことは考虑に入れねばならないところであ る(第8表).

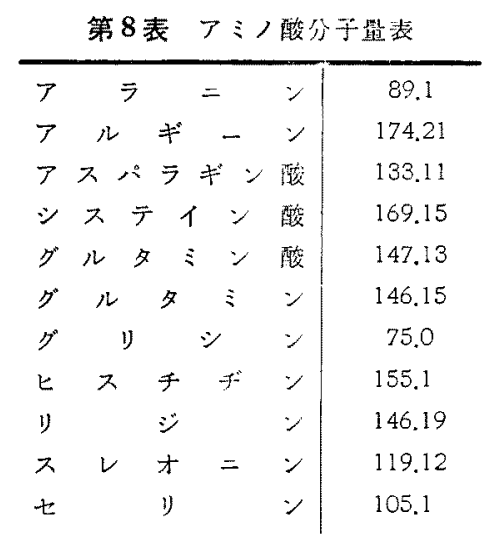

\section{第 5 章 結語}

1/200 希橎及び 1/500 希釈のクロトン油をモルモツト の口蓋に注射すると，1待間後にその外リン゙゙派に第1 部でのベたク種類のアミノ酸の他に新たに4種のアミ， 酸が出現することをのべた，更にこのよらな变化はタ口 
トン油を腹部皮下に注射した場合には決して起らず，口 蓋と云う場所的特異性によるものでありこれが Reilly
現象に基ずく内耳-血管の透過性昂進によつて起るすのと 推諭し，交献的考察をも行つた。

\section{第3 部 モルモツト䯣液の遊離アミノ酸について}

\section{第 1 章 緒 武}

第1 部化おいて私はモルモット外リンバ液の遊離つミ ノ酸について述へ，更に外りンパ液の生成機転に関する 拷察を行つた，そしてその中で外リンバ液はその多ぐ 血管よりの分泌に，一部を蝸牛小管を通じて䚪液からの 供給によつているのであ万うとのべてきた，私恃この点 を更江深く研究するため，モルモット骮液の游離了ミ， 酸の分析を行い，外リンパ液と比較検討しょうと試み た。

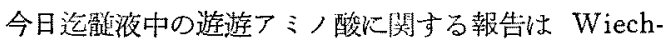
mann et al ${ }^{61}$, Harris ${ }^{12}$ ), Richiter et al ${ }^{40}$, Solomon 48), Torre et al ${ }^{54)}$, Alava ${ }^{1)}$, Ludewig et al ${ }^{\text {29) }}$, Walker et al ${ }^{60}$ ), Knauff et al ${ }^{21}$ ), Schiavini ${ }^{43)}$, Schönberg ${ }^{41)}$, Shidara ${ }^{46)}$, Kemali ${ }^{19)}$, Logothetis ${ }^{27)}{ }^{28)}$, 等( 上る正常者, 各種神絽疾患患者に関する研究が双ら机る がモルモツトに関するるのは見られない，

又次に口蓋刺激後に外リンパ液の場合上同様髓液にも 遊離アミノ酸構成の变動が起こるが否が追求した。こ の問題の解明は外リソパの生成機転や組成の变動の起こ る場所を知る上にきはめて重要である。しかしながらこ れ関する先人の報告はこれ又るつたくなされていな い.

\section{第 2 章 実験方法}

実嘒動物として，体重 $300 \mathrm{~g} \sim 400 \mathrm{~g}$, 主として雄性のア ルビノモルモット使用した。 その他の条件壮第1 部に 述べたと同様である。

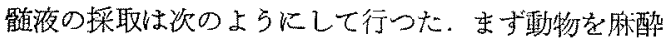

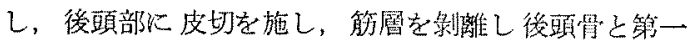
頸椎との間で硬膜を露出する．ここに先端の直経約 0.2 $\mathrm{mm}$ のガラス管を刺入すると液は暇液圧によつて自然 に上呰する。

麻酔による影響をしらべるためェーテル麻酔と $25 \%$ ウレタン腹腔内注射麻酔の 2 法を浒用した。

採取した榆体は計量の後，第 1 部にのべたと同様二次 元ペーパークロマトグラフ法に上り,その遊襍アミノ酸 を測定した。

検体の量は外リンバの場合と比较するためほほぼ同量，

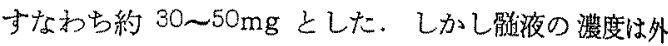
リンパ液よりもややうすいように思はれ，そのため若干 多めにした方がよい結果が得られた。一匹のモルモット からは歷に 200〜300mg の骮液を採取し得るので外り ンバ液の場合と買り一匹分の一部によつて一回の実融を 行い得を.

除蛋白その他の処理は行なはなかかた。 その他測定条 件は外リンパ液の場合之同一条件である。

次に口蓋刺激の方法としては第二部で述べたと同様 1/200 及び1/500に希积したクロトン油を用い，これを 動物の両側颠口盖汇各 $0.1 \mathrm{cc}$ 宛注射し，1時間後に路液 を採取した。これを同じく二次元ペーパークロマトグラ フ法によりその遊離アミノ酸を測定した。

\section{第 3 章 実 験 結 果}

このようにして得られた結果は，まず正常時について 見ると第9表に示すと教りである。すなわらがルタミ ン,アラニン、スレオニン，グリシン，セリン，グルタ ミン酸, アスパラギン酸, アルギニン，ヒスチヂン，リ ジン，パリン，ロインンの12 種類の遊離フミノ酸を检 出することができる。

第9表 正常モルモツト蹎液遊離アミノ酸

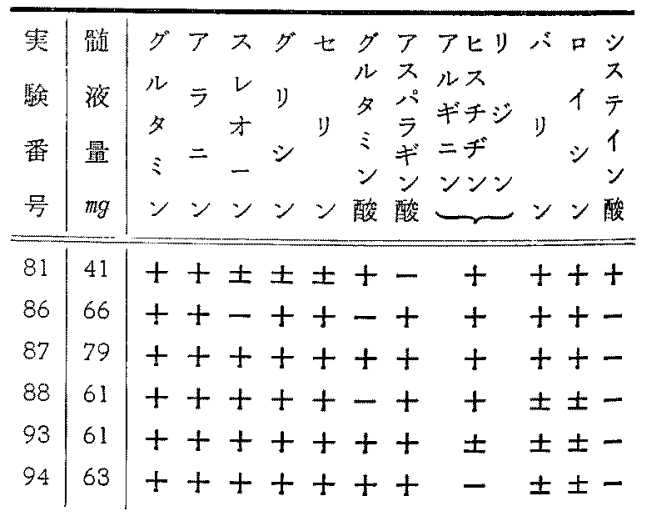

次に口蓋刺激後の顝液に見られるアミノ酸は第10表 に示すと括りであつて，正常の場合とまつたく異なると ころがなからた。 


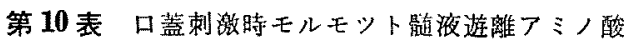

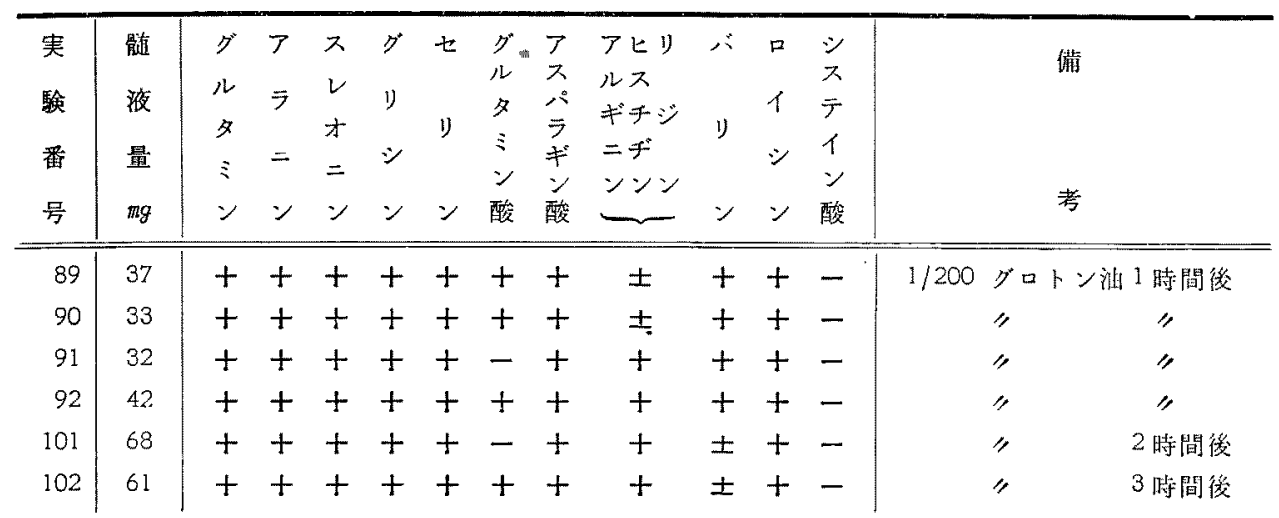

\section{第 4 章 総括及び考按}

以上の結果を外リンパ液の場合と比較すると, その主 たる構成成分は同一であるが，更に 5 種類も多くのbの が検出されて就り，両者の間に明らかな相違のあること が分かる.

第二部において私は諸家の説を総合しつつ外リンパ液 の起源について述ベたが，この事夷も文りンハ液と檤液 の関連性についての基礎的知見に役立つものであるら。

元来霄液は内耳液と異り生体から容易に，しか子大量 に採取し得るので, その生化学的研究す 19 世紀末(Key u. Retzius 20) 1875) すで以苸生えており，特以神絽系 疾患との関連に扎いて多くの研究吕なされている。

そして髄液と内耳液との相関的研究は色素等の異物に

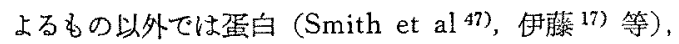
電解質 (三宅 ${ }^{32)}$ 等)，などによるものが見られるが， アミノ酸による比較は行は机ていない。

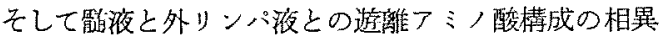
はこの两者の構成自体の相翼につながるるのであり，こ の事突は諸家の研㠰絬果ともよく一致するものである。

定量的分析は行つていないのでてミ，酸の潘度に言及 することはできないが，一般的に云つて剈液の方がやや 濃度が低い上らに思われる。このことは $30 \mathrm{mg}$ 以下の 試料では哏液の場合にはアミ，酸が整めて检出し難くな

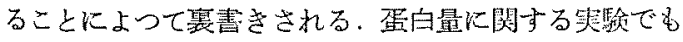

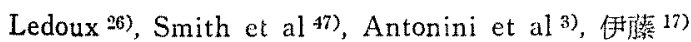

等いずれ歹䯙液の濃度は外リンバ液の数分の1にすぎな いよしているのである。

さて次に口盍刺激後の䯣液アミノ酸についてのべて見 ると，既述のように髄㖡に扰いては外リンパの場合と畏 り，口蓋刺激によつてその遊離てミノ酸構成に変動をき たすことはない，従つて外りンパ起つた変化畒顝液が 蝙牛小管を経由して外リンパ流れ込んだために起つた のではなく，外リンパそれ自体における変化であると云 うことが確認された訳である。その絽路は第 2 部で精説 した如く血管系一ラセン政带一以外には存在しない，去 れ故神経血管系の反応与な⿰ち Reilly 現象に上つて外 リンパの変化が生じたのではないかと云ら考えは，本実 歌によつて更に强い裏付けを得たと云克よう。

\section{第 5 音 結語}

モルモツト能液の遊離アミ，酸を二次元ペーバークロ ーマトグラフ法によつて測定し，グルタミン，アラニン， スレオニン，グリシン、セりン，グルタミン酸，アスパ ラギン酸，フルギニン，七スチヂン、リジン、バリン， ロイシンの12種類を检出したそとして外リンパ液と䯣 液との相晎点をアミ，酸構成の面から明らかにした。次 にこの棈成が外りンバ液の場合と異り口蓋刺湤によつて 变動をきたさないことを述べこのことから口蓋刺湤に よる外リンハ液の变化は蹎液に起源を有さず，外リンバ

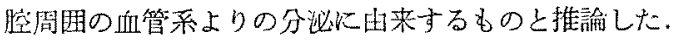


第 4 部 モルモツト外リンパ液, 䯣液, 血清中の C.R.P.について

\section{第1章 緒言}

C.R.P. (C-reactive protein) は1930年 Tillett, Francis ${ }^{52)}$ によつてはじめて報告されたものである，彼等 は肺炎球菌菌体成分の多糖類 C 分画が，肺炎患者の血 清と沈降反応を起こすことに注目した。この反応はやが て脚炎患者のみならず各種の細菌性疾患患者の血清にお。 いても起ることが見出され，その特異な反応様式から， これは抗原抗体反応とは別個のものであるうと考点られ るようになつた。

そしてこの物質は硫酸アンモン法ではアルブミン分画 に, 電気泳動法では $\alpha, \beta$ グロブリンに属する蛋白性物 質であることが確められた，更に McCarty ${ }^{309}$ は人及 びサル以外の動物血清中に出現する $\mathrm{C}_{\mathrm{x}}$-多糖類を分離 した．これは本質的には C 多糖頪と同一の物質である が，C 多糖類の沈降反応上り鋭敏である.

さて，この C.R.P. が陽性化する疾患として，各種の 炎症性疾患，悪性腄瘍，リューマチ熱等が知られている

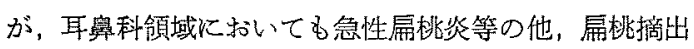
術施行後 5)にも出現を見ることが多い，

このように C.R.P.は急性期に際し，原因と関係なく 非特異的に出現するいは河る急性期反応物質の一種であ り, その起源, 生成機序などについては, 細網内皮系産 生説等もあるが，な怙充分に解明されていない。

一方 Chevance ${ }^{8}$ )。伊藤 ${ }^{17)}$ はモルモットの口蓋化刺 漖を加えた際の内耳液, 野淮, 血清の C.R.P. の動きを 追究し, C.R.P. 出現は対する自律神経の役割を重視し ている.

私はこれまで口蓋刺激が内耳液に及ぼす影響を，遊離 アミノ酸を指標として研究してきたが, 次にこのC.R.P. を指標として研究し，若干の知見を得ることができた。

\section{第 2 章 実験方法}

実駼動物として，遊離厂ミノ酸の研究に用いたのと同 様体重 300〜400g の健康な雄性アルビノモルモットを 使用した。

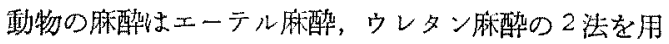
いた。

䏫醮後，まず後頭骨之第一頸椎の間上り後頭下穿刺に より檤液を採取, 次いで断頭し頸動脈より採血, 最後に 中耳胞を開放し正円究より外リンバ液を採取した。

採取した検体沈 $56^{\circ} \mathrm{C} 30$ 分間加熱非動化し，Hyland 社製 CR-test によつてその C.R.P. を測定した.
一般に C.R.P. の測定には毛細管内で被検血清と抗血 清を接触させてその反応を見る capillary precipition method が用いられているが，私の場合の上引極く微 量, 低濃度でしかる対照が $C_{x}$. R.P. である時はHyland 社の㠜集反応方式の方が適当と思はれるのでこれを採用 した。

外リンパ液，蹎液の場合はその蛋白濃度が血清のそれ に比較して極めて低いことが知られているので，私はこ の両者については湅結乾燥法により5〜10 倍に嵈縮した ものも検討した，この場合乾懆後の溶解忆は綏衝液を用 Wた.

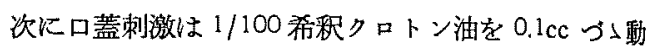
物の両側軟口蓋に注射することによつて行つた。

口蓋刺激から1時間のち，先にのべた方法で血清，咀 液，外リンハ液を採取し，その C.R.P. を睍定した。

\section{第 3 章 実験結果}

まず正常例比括いては血清，䯘液，外リンパ液共 C.R.P.の出現を見ない(第 11 表)，䯣液，外りン八液 の場合は湅結乾燥法に上る濃縮を試みたことは前章にの ベたが，その結果も第12表にみられるよう陰性であ

第 11 表 正常モルモット外リンパ，噵液， 血清 C.R.P.

\begin{tabular}{|c|c|c|c|c|}
\hline No. & 外リンパ & 液 & 血 & 供 \\
\hline 3 & - & - & - & ウレタン麻蠤 \\
\hline 4 & - & - & - & " \\
\hline 5 & - & - & - & " \\
\hline 7 & - & - & \pm & エーテル麻醉 \\
\hline 8 & - & \pm & - & " \\
\hline 9 & - & - & - & $"$ \\
\hline 10 & - & - & - & " \\
\hline
\end{tabular}

第 12 表 漕樎時正常モルモット外リンパ 檤液 C.R.P.

\begin{tabular}{|c|c|c|c|c|c|}
\hline No. & 外リンハ、 & $\begin{array}{c}\text { 量 } \\
\mathrm{mg}\end{array}$ & 踏 液 & 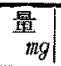 & 備 \\
\hline 12 & - & 15 & - & 193 & 外リンパ液は 3 匹分 \\
\hline 13 & - & 10 & - & 219 & " \\
\hline 14 & - & 17 & - & 176 & " \\
\hline 15 & - & 14 & - & 252 & $"$ \\
\hline 16 & - & 11 & - & 238 & " \\
\hline 17 & - & 18 & - & 206 & " \\
\hline
\end{tabular}


る。試料の絶対量の問題もあると思はれるので外リンパ 液は 3匹分ををとめたものについて調べたが，総量 20 mg 以下の範囲では結果汇変りはない.

次に口蓋刺激後 1 時間のものを見てみるとその結果は 第 13 表のと赫りである．即ち血清沈おいて 60\% の陽性 化率をみているのである.监液，外りンパでは陽性化率

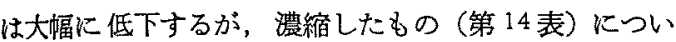
て見ると率はやや高くなる。

対照として腹部皮下に同量のクロトン油を注射したも のについて見ると第 15 表の如く正常の場合と全く差が 見られない。

第 13 表 口蓋刺激時モルモツト外リンパ， 檤液，血清 CRP

\begin{tabular}{|c|c|c|c|c|c|}
\hline No. & $\mid$ 外リンパ & 蹎 液 & 血 清 & 備 & 考 \\
\hline 20 & - & + & $H$ & $1 / 100$ & クロトン油 \\
\hline 21 & - & - & + & & " \\
\hline 22 & - & $t$ & $t$ & & " \\
\hline 23 & - & + & + & & $"$ \\
\hline 26 & - & - & \pm & & $"$ \\
\hline 27 & - & - & \pm & & $"$ \\
\hline 28 & - & - & - & & " \\
\hline 29 & - & - & - & & " \\
\hline
\end{tabular}

第 14 表口蓋刺激後濃縮時モルモット 外リンパ, 䯣液 C.R.P.

\begin{tabular}{|c|c|c|c|c|c|}
\hline No. & 外りンㅇ & $\frac{\text { 量 }}{m g}$ & 留道 液 & $\begin{array}{c}\text { 量 } \\
\mathrm{mg}\end{array}$ & 埨 \\
\hline 40 & 一 & 10 & - & 152 & 外リンパ 3 匹分 \\
\hline 43 & 一 & 15 & + & 220 & " \\
\hline 44 & + & 14 & + & 198 & " \\
\hline 45 & - & 18 & - & 259 & $"$ \\
\hline 47 & - & 8 & - & 213 & 外リンパ 2 匹分 \\
\hline 48 & + & 9 & + & 207 & " \\
\hline 49 & \pm & 12 & - & 181 & " \\
\hline
\end{tabular}

第 15 表 腹部皮下クロトン油注射後外リンパ 蹎液，血清 C.R.P.

\begin{tabular}{|c|c|c|c|c|}
\hline No. & 外リンパ & 䯙液 & 血綗 & 備 \\
\hline 33 & 一 & - & - & 1/100クロトン油 1 時間後 \\
\hline 34 & - & - & - & " \\
\hline 35 & - & - & - & " \\
\hline 36 & - & - & - & " \\
\hline 37 & - & - & - & $"$ \\
\hline
\end{tabular}

\section{第 4 章 総括及び考按}

以上私はモルモット外リンパ液，咀液，血清中の C.R.P. について确究し，クロトン油口蓋刺激淩1 時間 で，特に血清中 C.R.P. が晹性化することを知つた。こ の中で特に重要な意義を有するのは 1 時間と云ら短時間 に C.R.P.が陽性化すると云う事実である。これは Chevance ${ }^{8)}$, (伊藤 ${ }^{17)}$ むすでK認めていることがあるが，こ の時間的な早さと，クロトン油を腹部皮下に注射したた けでは陽性にならないと云うことなどから，口蓋部位の 刺激と云弓局所的要因と C.R.P. の出現とは密接な関係 が考えられる、しかしながらこれは今まで私がのべてき たアミノ酸の変動とは全く異る面を有している，即ちて ミノ酸の場合は血中に正常に存在するアミノ酸が内耳血 管透過性の変化によつて外リンパ液中に出現すると考兄 られるが，C.R.P.の場合は明らかに正常には存在しな い蛋白性物質が口蓋刺激によつて新たに出現してくるの である。

さてこの C.R.P. の出現機序については不明の点が多 い，クロトン油は催炎症性物啠であるが口蓋注射の場合 と腹部皮下注射の顕著な差は，口蓋と云う部位の場所的 特異性を重視しない訳にはいかない，C.R.P.の生成部 位が細網内皮系しすれば自律神経との密接な関係は首背 される所である.従来の報告によれば炎症発現後 C.R.P. の出現迄の時間は少くとも6時間以上を要する50)。これ は私の成績とはかなり相違しているが，あるいは口蓋刺 激一自律神経刺激が C.R.P. の形成学促進するのか子知 れない. 扁摘施行後の患者の C.R.P. が特別早期に出現 すると云ら報告はないが，短時間内の変動は追求してい ない場合が多いので比較はなし得ない、いずれにせよ動 物実験の結果によつてこのよらな問題をで早急に論ずる ことは種々不足があり，出現機序の点については今後の 研究にまたねばならない。

外リンパ液，䯣液に竹ける C.R.P.の出現率は血清に 括けるよりもはるか以低率であつたが，これは一部には その蛋白濃度の差にも上ると思はれる。濃縮も試みたが 量的な限界もあり血清蛋白濃度と同程度迄濃鏥すること はできなかつた，いずれにせよかかる異常蛋白が早期に 外リンバ液にまで現れると云うことは大きな問題であ り，これが内耳機能になんらかの影響を与充得る可能性 も当然考えられる所である。

\section{第 5 章 結語}

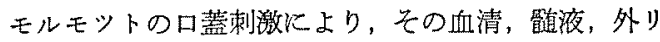
ンパ夜中に正常には決して存在しない一種の異常蛋白物 
質 C.R.P. が高率に出現するが，その様式の特異性から 自律神経性要素が大きいと想像されることについてのべ た. 更に C.R.P. の出現機序，意義等について考察した がこれらの点にはな括不明の点が多い。

\section{參考文献}

1) Alava, A.G.: Clin. y. Labor. 64: 253, 1957. 2) Aldred, P., et al: J. physiol. 98: 446, 1940. 3) Antonioni, E. et at: Annals of ORL. 56: 129, 1957. 4) 秋山登：日耳鼻, 59:1237, 1955. 阿部缭一，他：日耳舅，66:1404, 1963。 6) Berger, M.: Rev. de Laryng.Otolog.-Rhinologie 83 : 925, 1962, 7) Chevance, L.G.: Acta Otolaryng. $49: 509,1958 . \quad$ 8) Chevance, L.G.: Acta Otolaryng. 50:37, 1959.9 9) Flaschentrager: Helv. chem. Acta 17: 1444, 1934 10) 深沢久夫：耳舆 咽倁科，30：169,1958. 11) 後藤修二, 他: 日耳 梹, 61: 394. 1957. invest. $22: 569,1943$.

12) Harris, M.: J. clin. J. Laryng. Otolog. 72: 117, 1958 . 14) 趾田稳：耳 鼻咽喉科，30：169，1958. 15) 五十嵐篤男：日耳

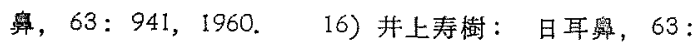
$995,1960,17)$ 伊藤明和: 日耳鬼, 64:923, 1961 .

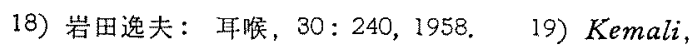
D.: Acta neurol. 12: 419, 1957. 20) Key, A..

Retzius, G.: Anatomie des Nervensystems und des Bindegewebes. Stockholm 1875. 21) Knauff, $H$. G. et al: Klin. Wschr. 36:739, 1958.

22) 澡地 三通男：耳鼻臨，50: 508，1957. 23) 小出嗉：耳 與臨，50：377，1957.24）會井秀夫：日耳鼻，63： $1701,1701,1960$. 25) Laborit, H.: Réaction organique á l'agression et choc 1955.26$)$ Ledoux, A.: Acta med. Belg. 1950. 27) Logothetis, J.: Neurol. 5, 767, $1955 . \quad 28)$ Logothetis, J.: World Neurol. 2: 747, 1961. 29) Ludewig, S.: Arch. Neurol. Psychiat. $70: 268,1953 . \quad 30) M c$ Carty.: J. Exp. Med. 93:25, 1951. 31) 松生策

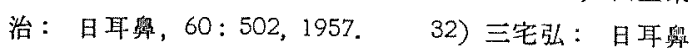
61回総会シンポギウム。 33) Nomura，Y.: Annals of ORL. 70:81, 1961.34) 永瀨邦彦: 日耳医，61: 1480, 1958. 35) Ottaviani, A. et al: Acta Otolaryng. $56: 715,1963$. 36) 大野交朗：日耳聯，63:
56, 1960.037$)$ Perlman, H.B. et al: Annals of ORL. 64: 1176, 1955, 38) Portmann, G: Rev. de Laryng.-Otolog.-Rhinologie 52 : 467, 1931.39 ) Reilly, J. et al: Soc, de Biol. 1934. 40) Richter, D. et al: J. ment. sci. 95:148, 1949. 41) Ricker, G.: Entwurf einer Rerationspathologie G. Fischer Verlag 1905. 42) Rüedi, R.: Annals of ORL. 60:993, 1951. 43) Schiavini, A.C.et al: Minerva pediat. $9: 1486,1957 . \quad$ 44) Schönberg, H.: Z. Kinderh. 75: 301, 1954.45$)$ Selye.: 適応症候群 (田多井訳)，1952. 46́) Shidara, R.: J. indust. inst. ment. Health 2, 2, 1959 . 47) Smith, C.A. et al: Laryngoscop. 64:141, 1954. 48) Solomon, J.D.: J. biol. chem. $171.675,1947$ 49) Speransky, A.D.: A basis for theory of medicine 1943 . 50)塩川優一，他：蹦床病理，5:4, 1957.51 ) 杉 山繁：日耳奥，67：631，1964. 52) Tillet, W.S. et al: J. exp. med. $52: 561,1930.53)$ Tonndorf, G. et al: Annals of ORL. $71: 801,1962$. 54) Torre, M.: Boll. soc. ital. Biol. sper. 29 : 196, 1953. 55) 高垣玄吉郎：屡応医学, 5:7,1964。 56) 玉川 健二郎：日耳率，63:978，1960. 57) 坪井邦夫:

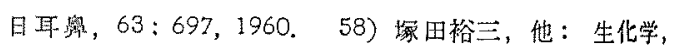
33: 51，1961.59) 日井大一郎：日耳鼾，67:1215, 1964. 60) Walker, B.S. et al: Arch. Neurol. Psychiat. $73: 148,1955 . \quad$ 61) Wiechmann, E. et al: Dtsch. Arch. Klin. Med. 1. 153: 1926. 62) 渡辺嘉彦：日耳率，64:1325, 1961。63) 山崎嘉司: 日耳鼻，66:940, 1963.64$)$ 吉川久夫：日䕗， $58: 696,1955$.

稿を䅂るに臨み，終始御指導，御校閲を䧉易つ た思師鈴木安恒教授に梁甚なる謝意を表すると 共に，御教示をいたたいた本学薬理学校室細谷 英吉教授，秹藤章二助教授並びに教室員各位に 感媩する。

本諭文の要旨恃日本耳楀咽唉科学会第64回総 会, 日本耳率咽喉科学会関東地方会第 401 回例 会，第45回総会に打いて発表した。

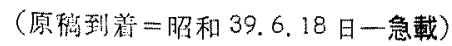

